\title{
A Functional Proteomic Approach to the Identification and Characterization of Protein Composition in Wheat Leaf
}

\author{
Jung-Feng Hsieh ${ }^{1}$ and Shui-Tein Chen ${ }^{2, *}$ \\ ${ }^{1}$ Department of Food Science, Fu Jen Catholic University, Xin Zhuang, Taipei 242, Taiwan and ${ }^{2}$ Institute of Biological \\ Chemistry and the Genomics Research Center, Academia Sinica, Nankang, Taipei 115, Taiwan
}

\begin{abstract}
Proteomics and bioinformatics approach were applied for the analyzing of wheat leaf proteins' composition and function. Wheat proteins were precipitated by ammonium sulfate and analyzed by two-dimensional gel electrophoresis and mass spectrometry. A total of 200 wheat proteins were selected to identify based on reproducibility and relative quantity, and 123 proteins were identified with an identification success rate of $61.5 \%$. The classifications of these proteins by BGSSJ (bioinformatic software) were mainly classified by their molecular, biological and cellular function. Proteins grouped under the molecular function were involved in catalytic, binding and antioxidant activity. The catalytic activity of identified wheat proteins included oxidoreductase, transferase, hydrolase, lyase and isomerase. Only $10.6 \%$ of the wheat protein identifications lacked ascertainable functions. These results provided the information to investigate the composition and function of proteins found in wheat leaf, and enhanced the feasibility of future research on wheat.
\end{abstract}

Key Words: Proteomics, 2D-PAGE, wheat leaf, protein composition, mass spectrometry.

\section{INTRODUCTION}

Wheat is one of the most important cereal crops in the world. Consumption has doubled in the past 30 years to nearly 600 million tons per year. The International Maize and Wheat Improvement Center has stated that the worldwide demand will increase by over $40 \%$ by 2020 (Donnelly, 2005). Knowledge acquirement of wheat's biochemical constitution and functional biology are required to improve wheat in ways that can meet this demand. Recently, scientists have shown a great interest in investigating the function of wheat leaf proteins (Saxena et al., 2000). Two-dimensional gel electrophoresis (2-DE) is a useful tool to explore the wheat proteins (Rampitsch et al., 2006). For 2-DE analysis, many neutral salts such as ammonium sulfate (AS), sodium chloride and sodium sulphate have been used to precipitate or fractionate proteins (Englard and Seifter, 1990). AS has been the precipitant used most frequently in the salting out of proteins by stepwise precipitation, and has been used to concentrate proteins from microorganism, animal and plant tissues (Farag and Hassan, 2004; Su and Yang, 2000; Kochkina, 2004).

The 2-DE approach to protein profiling has been successful because it is an accessible, inexpensive and powerful tool for analyzing patterns of protein expression. All protein spots that have been resolved and detected within the $10^{4}$ to $10^{5}$ dynamic range of gel capacity can be studied qualitatively and quantitatively in relation to each other, and viewed as a single image (Bahrman et al., 2004). Two-dimensional difference gel electrophoresis has strengthened the 2D platform by allowing the detection and quantization of diffe-

*Address correspondence to this author at the Institute of Biological Chemistry and the Genomics Research Center, Academia Sinica, Nankang, Taipei 115, Taiwan; Tel: +886-2-27886230; Fax: +886-2-27883473;

E-mail: bcchen@gate.sinica.edu.tw rences between samples resolved on the same gel, or across multiple gels, when linked by an internal standard ( $\mathrm{Wu}$, 2006). This technique is based on the protein samples with fluorescent cyanine dyes, which have distinct excitation and emission spectra and are movement (charge and size) matched. Therefore, the same protein labeled with any of the dyes (Sypro ${ }^{\circledR}$ Ruby dye, silver nitrite, Cy3 or Cy5) will move to the same position within a 2D gel (Trisiriroj et al., 2004; Dhingra et al., 2005; Topanurak et al., 2005).

2-DE, combined with protein identification by mass spectrometry (MS), has often been employed to identify individual protein of interest. For function classification of these identified proteins, BGSSJ (bioinformatic software, http:// sourceforge.net/projects/bgssj/) is used. This software was developed by our laboratory, and is an XML-based Java application for BGSS (Bulk Gene Search System) that organizes selected proteins for biological interpretation (Juan et al., 2002). BGSS integrates UniGene (http://www.ncbi. nlm.nih.gov/UniGene/), Locus Link (http://www.ncbi.nlm. nih.gov/LocusLink/index.html), Proteome (http://www. proteome.com/databases/HumanPD/reports), SWISS-PROT (http://www.expasy.ch/sprot/), PubMed (http://www.ncbi. nlm.nih.gov/ PubMed/) and SubtiList (http://genolist.Pasteur. fr/Subti List) databases. The classifications of functional annotations of these proteins were mainly classified in molecular, biological and cellular function. Therefore, the objective of this study was to investigate the protein composition and function in wheat leaf by the proteomic approach and combined with MS and bioinformatic software.

\section{MATERIALS AND METHODS}

\section{Plant Material and Protein Precipitation}

Wheat (Triticum aestivum L.) seeds were planted individually in $4 \mathrm{~cm}$ diameter $\times 20 \mathrm{~cm}$ high containers. These 
seeds were grown in chambers with $24: 18^{\circ} \mathrm{C}$ day:night temperature cycle and $14 \mathrm{~h}$ photoperiod for 10 days. Wheat leaves were harvested, milled by a laboratory-scale milling machine and filtered through filter paper. The extract was then salted out with solid AS and collected at 0-40, 40-60, 60-70, 70-80, 80-100\% (w/v) saturation of AS, respectively. Each fraction was collected by centrifugation $(12,000 \times \mathrm{g}$ for $40 \mathrm{~min}, 4^{\circ} \mathrm{C}$ ) and dialyzed extensively against phosphate buffer $(50 \mathrm{mM}, \mathrm{pH} 7.5)$ at $4^{\circ} \mathrm{C}$ for $24 \mathrm{~h}$. The precipitated proteins were suspended in a chilled $\left(-20{ }^{\circ} \mathrm{C}\right)$ solution containing $10 \%$ TCA, $90 \%$ acetone with $0.07 \% \beta$-Me. The mixture was incubated at $-20^{\circ} \mathrm{C}$ for $4 \mathrm{~h}$, and then centrifuged at $12,000 \mathrm{xg}$ for $40 \mathrm{~min}$. The pellet was washed three times with $5 \mathrm{ml}$ of chilled $\left(-20{ }^{\circ} \mathrm{C}\right)$ acetone with $0.07 \% \beta$-ME centrifuging at $12,000 \mathrm{xg}$ for $40 \mathrm{~min}$ between rinses.

\section{Protein Quantification}

Protein concentration was determined by the Bio-Rad protein assay (Bio-Rad Laboratories, Hercules, CA), and the ovalbumin (Sigma, St. Louis, MO, USA) was adopted as the standard (Chao and Nylander-French, 2004). Bio-Rad protein assay dye was diluted with water 3 times the volume, and then mixed into the standards or samples. Samples were left at room temperature for $2 \mathrm{~min}$ before absorbance, which was determined at $595 \mathrm{~nm}$ using a UV spectrophotometer (Beckman DU640; Beckman Instruments, Palo Alto, CA).

\section{Sodium Dodecyl Sulfate-Polyacrylamide Gel Electropho- resis (SDS-PAGE)}

Wheat samples were first analyzed by SDS-PAGE, which was performed by using the precast Novex ${ }^{\circledR}$ Tris-glycine gels (Invitrogen Co.). Samples, reducing agent and sample buffer were denatured by heating in boiling water for $3 \mathrm{~min}$. The sample buffer contained $10 \%$ glycerol, $70 \mathrm{mM}$ Tris- $\mathrm{HCl}$, $\mathrm{pH} 6.8,2 \%$ SDS, and $0.02 \%$ bromophenol blue. Protein ladder and samples $(10 \mu \mathrm{g})$ were then loaded into separate wells. After electrophoresis, gels were added in a solution containing $10 \%$ methanol and $7 \%$ acetic acid for $30 \mathrm{~min}$, then stained in $350 \mathrm{ml}$ of the Sypro ${ }^{\circledR}$ Ruby protein gel stain solution overnight, before soaking in deionized water for 20 min to wash the residual dye out (Berggren et al., 2000). The developed gels were digitally scanned as 2-D images by using fluorescence image scanning Typhoon 9200 (Amersham Pharmacia Biotech), and analyzed by ImageMaster software (Amersham Pharmacia Biotech).

\section{Two-Dimension Gel Electrophoresis and Image Analysis}

Wheat samples were dissolved in lysis solution containing $7 M$ urea (Boehringer Mannheim, Germany), $2 M$ thiourea (Aldrich, WI, USA), and 4\% CHAPS (J. T. Baker, NJ, U.S.A). For the first dimensional separation, $500 \mu \mathrm{g}$ of total protein was immobilized and loaded into $\mathrm{pH}$ gradient (IPG) gel strips ( $\mathrm{pH} 4-7,18-\mathrm{cm}$ long, Amersham Pharmacia Biotech, Uppsala, Sweden), which were rehydrated for $12 \mathrm{hrs}$ in a solution containing $7 M$ urea, $2 M$ thiourea, $4 \%$ CHAPS, 40 $\mathrm{m} M$ Tris-base, $2 \%$ IPG ampholyte, $65 \mathrm{~m} M$ DTE and $0.0002 \%$ bromophenol blue prior to use. The strips underwent isoelectric focusing with the use of the IPGphor system (Amersham Pharmacia Biotech) at $20{ }^{\circ} \mathrm{C}$ with $6000 \mathrm{~V}$ for a total of $65 \mathrm{kVh}$, followed by having the strips equilibrated for 15 minutes in the equilibration solution $(50 \mathrm{mM}$ Tris-
$\mathrm{HCl}, \mathrm{pH} 8.8,6 \mathrm{M}$ urea, 2\% SDS, 30\% glycerol, 2\% DTE), then added with $0.5 \%$ agarose to the top of a vertical $8-18 \%$ linear gradient SDS-polyacrylamide gel. Second dimensional electrophoresis was carried out with PROTEAN II MULTICELL (Bio-Rad, Hercules, CA, U.S.A) at $45 \mathrm{~mA}$ per gel for $5 \mathrm{~h}$ until the bromophenol blue reached the bottom of the gel. The gels were immersed in 10\% methanol and 7\% acetic acid for 30 minutes, then left in $350 \mathrm{ml}$ of the Sypro ${ }^{\circledR}$ Ruby protein gel stain solution overnight, before soaking in deionized water for 20 minutes to wash residual dye out. The developed gels were digitally scanned as 2-D images by using fluorescence image scanning Typhoon 9200, and analyzed with ImageMaster software.

\section{Protein Digestion}

Selected spots were excised and de-stained by washing in a solution containing $250 \mu \mathrm{l}$ of acetonitrile $/ 50 \mathrm{~m} M$ ammonium bicarbonate $(1: 1 \mathrm{v} / \mathrm{v})$ for $15 \mathrm{~min}$ twice. The gels were dried by using a centrifugal vacuum concentrator. Reduction and alkylation for cysteine residues were performed on samples by using DTE and iodoacetamide, respectively. For tryptic digestion, the gel was rehydrated in trypsin solution $(12.5 \mathrm{ng} / \mathrm{ml})$ and incubated at $37^{\circ} \mathrm{C}$ for $16 \mathrm{~h}$. Peptides fragments were then extracted with equal volume $100 \%$ acetonitrile $/ 2 \%$ trifluoroacetic acid (TFA), sonicated in a bath for 10 minutes. The extracted peptides were concentrated by centrifugation in a vacuum centrifuge.

\section{MALDI-MS and MS/MS Analysis}

For MALDI-MS and MS/MS analysis, samples were premixed in a ratio of $1: 1$ with a matrix solution $(5 \mathrm{mg} / \mathrm{ml}$ $\mathrm{CHCA}$ in $50 \% \mathrm{ACN}, 0.1 \% \mathrm{v} / \mathrm{v}$ TFA and $2 \% \mathrm{w} / \mathrm{v}$ ammonium citrate) and spotted onto the 96-wells format MALDI sample stage (Tantipaiboonwong et al., 2005). Data were obtained directly on the Q-TOF Ultima MALDI instrument (MALDI ${ }^{\mathrm{TM}}$, Micromass, UK), which was fully automatic with predefined probe motion pattern and the peak intensity threshold for switching over from MS survey scanning to MS/MS, and from one MS/MS to another.

\section{Protein Identification}

Peptide mass fingerprint data from MALDI-Q-TOF were used to match the protein candidates in NCBInr, MSDB and Swiss-Prot protein databases using Mascot (http://www. matrixscience.com) search program (Gygi and Aebersold, 2000; Yates, 2000, Patterson and Aebersold, 1995). Search parameters allowed for methionine oxidation, cysteine carbamidomethylation, one missed cleavage site, and a peptide mass tolerance of 0.15 Da (Morrissey and Downard, 2006; Rashidi and Buehler, 2000). The product ion spectra generated by Q-TOF MS/MS were then compared against the NCBInr and Swiss-Prot databases and an exact match was found through the Mascot search program (Wan et al., 2001; Ahram et al., 2002). In addition, the identified proteins were searched for their annotation in description in the Swiss-Prot and NCBI protein databases.

\section{Functional Classification of Identified Proteins}

For functional classification of identified wheat proteins, we used BGSSJ, which is an XML-based Java application 
that organizes selected genes or proteins for biological interpretation in the context of Gene Ontology. It organizes information according to molecular function, biological processes and cellular components for a number of different organisms. The application allows for easy and interactive search in different protein identifiers (GenBank ID, UniGene, SwissProt), and generates a summary page that lists the frequencies of Gene Ontology annotations for each functional category (cluster). The visualization browser allows users to navigate the cluster hierarchy displayed in a tree diagram and explores the associated proteins of each cluster through a user-friendly interface.

\section{RESULTS AND DISCUSSION}

\section{Protein Precipitation and Wheat Leaf Proteome}

Wheat leaf proteins were salted out at 0-40, 40-60, 60-70, $70-80$ and $80-100 \%$ respectively (w/v) AS saturation (Table 1). A total of 5 fractions were collected and total yield of these fractions was $95.8 \%$. Total protein of each fraction was $88.6,491.3,163.2,53.6$ and $34.1 \mathrm{mg}$ respectively, while pro- tein content was $10.2,56.7,18.8,6.2$ and $3.9 \%$, respectively. Among these fractions, the highest and lowest protein content was present in the fractions precipitated with $40-60 \%$ $(56.7 \%)$ and $80-100 \%(3.9 \%)$ saturation of AS, respectively. Proteins obtained from each fraction were separated electrophoretically in the precast Novex ${ }^{\circledR}$ Tris-glycine gel (Fig. 1). SDS-PAGE showed significant differences in protein patterns for each fraction (L1-L6). However, L3 with highest protein content and its protein pattern was similar with L1. This indicated that most of the proteins could be precipitated at $40-60 \%(\mathrm{w} / \mathrm{v})$ AS saturation. Furthermore, these protein fractions were also separated electrophoretically in the 2D gels. We first analyzed the protein patterns of each fraction using 2-DE in the $\mathrm{pH}$ range of 3-10 (data not shown). The visualized wheat proteins crowded, appeared in a $\mathrm{pH}$ range of 4-7. Therefore, we further analyzed the protein patterns of these fractions by using 2-DE in the same $\mathrm{pH}$ range. The 2DE images of wheat leaf proteins (L2-L6) are shown in Fig. (2). The wheat leaf proteome was mapped and partially characterized to function as a comparative template for future wheat research. These protein maps will also enable future

Table 1. Fractional Precipitation of Wheat Leaf Proteins Using Ammonium Sulfate

\begin{tabular}{|c|c|c|c|c|}
\hline $\begin{array}{c}\text { Ammonium Sulfate } \\
(\%)\end{array}$ & $\begin{array}{c}\text { Volume } \\
(\mathbf{m L})\end{array}$ & $\begin{array}{c}\text { Total Protein } \\
(\mathbf{m g})\end{array}$ & $\begin{array}{c}\text { Protein Content } \\
(\boldsymbol{\%})\end{array}$ \\
\hline \hline Wheat extracts & 410 & 866.6 & 100.0 & 10.2 \\
\hline $0-40$ & 47 & 88.6 & 56.7 & 10.2 \\
\hline $40-60$ & 65 & 491.3 & 18.8 & 86.9 \\
\hline $60-70$ & 58 & 163.2 & 6.2 & 91.9 \\
\hline $70-80$ & 49 & 53.6 & 3.9 & 95.8 \\
\hline
\end{tabular}

\section{A $\quad$ B}
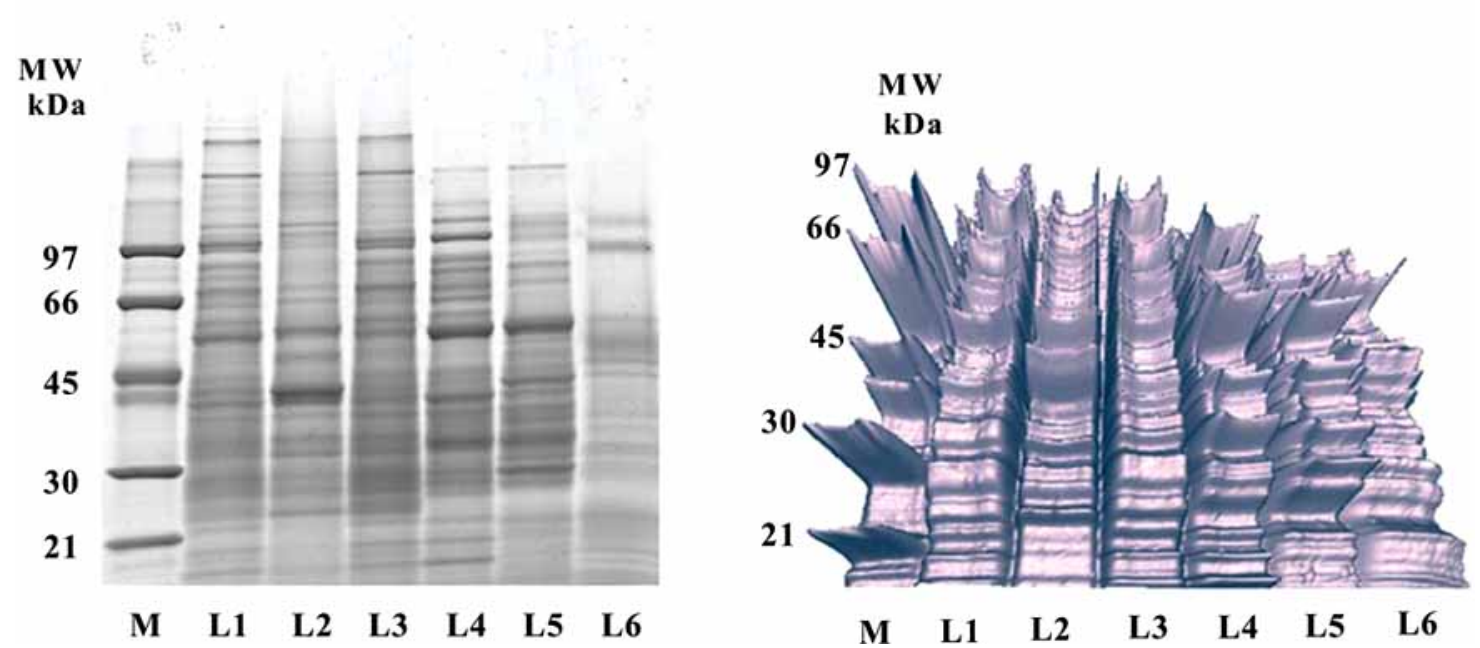

Fig. (1). SDS-PAGE analysis of wheat leaf proteins salted out with different concentrations of ammonium sulfate. M: protein marker; L1: wheat extracts; L2: 0-40\%; L3: 40-60\%; L4: 60-70\%; L5: 70-80\%; L6: 80-100\% of saturation ammonium sulfate. MW: molecular weight; A: SDS-PAGE image; B: 3D contour image. 


\section{L2-A}

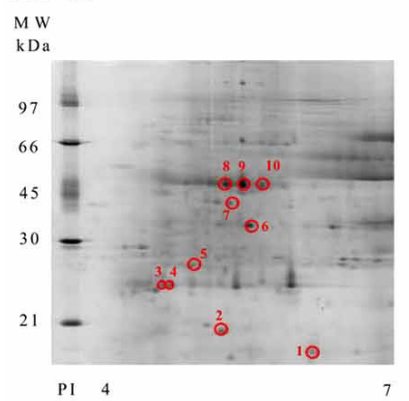

\section{L3-A}

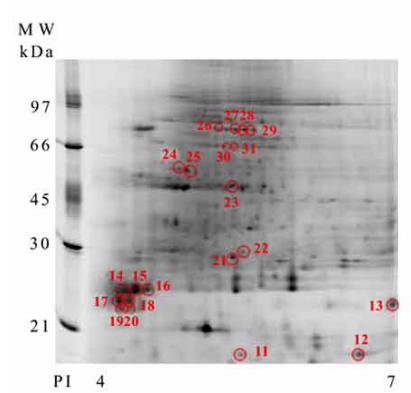

\section{L4-A}

$\underset{\mathrm{MDa}}{\mathrm{MW}}$

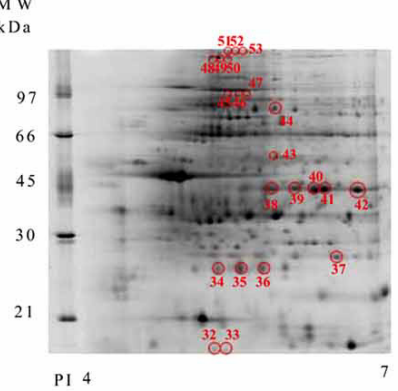

L5-A

$\mathrm{MW}$

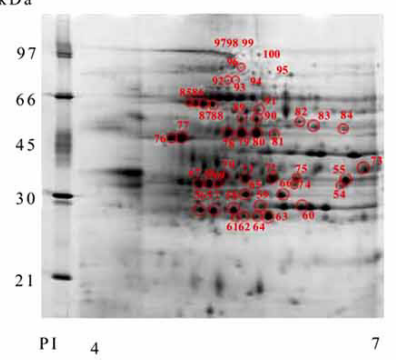

L6-A

$\mathrm{MW}$
$\mathrm{kDa}$

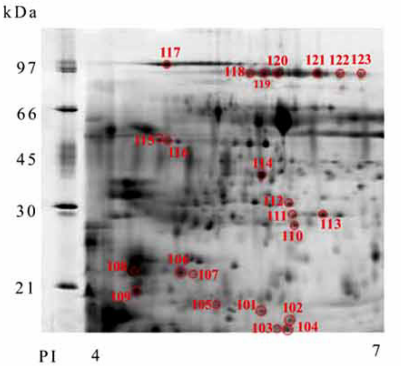

\section{L2-B}

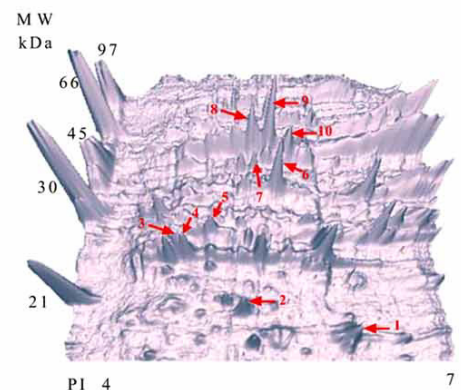

L3-B

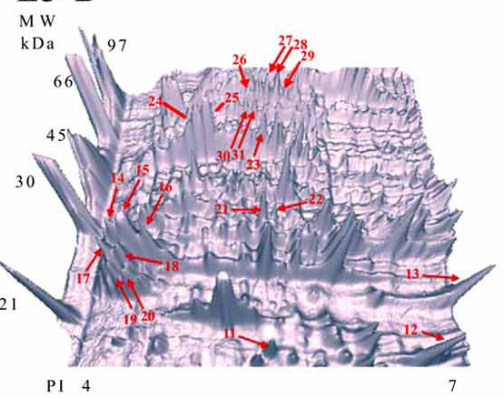

\section{L4-B}

$\underset{\substack{\mathrm{MW} \\ \mathrm{kDa}}}{\mathrm{C}}$

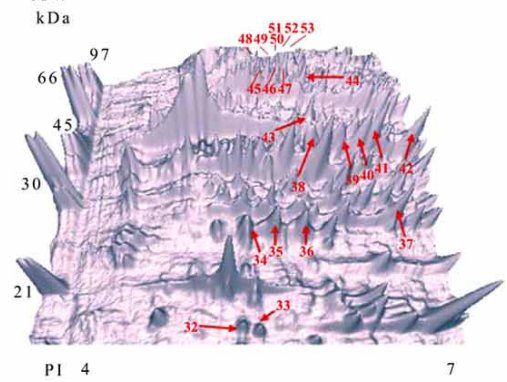

\section{L5-B}

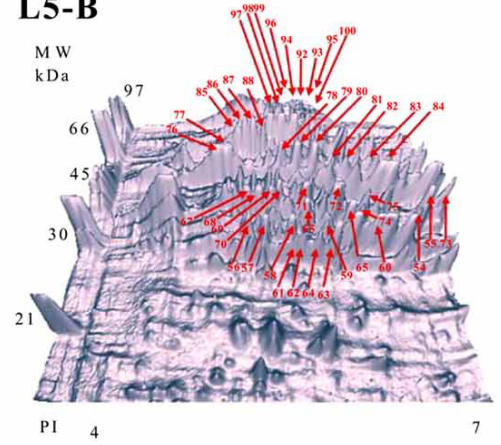

L6-B

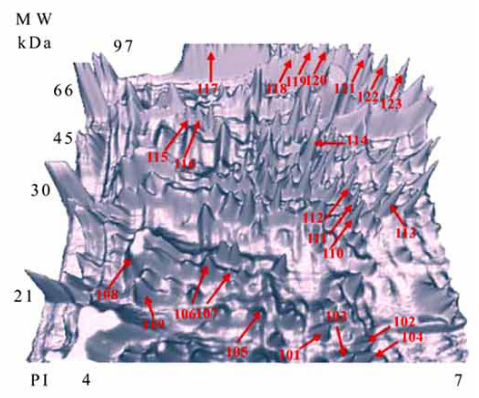

Fig. (2). Two-dimensional gel electrophoresis analysis of wheat leaf proteins salted out with different concentrations of ammonium sulfate. L2: 0-40\%; L3: 40-60\%; L4: 60-70\%; L5: 70-80\%; L6: 80-100\% of saturation ammonium sulfate. MW: molecular weight; A: 2-DE image; B: $3 \mathrm{D}$ contour image. 
proteomic studies to focus on differential expression using these cataloged proteins as reference proteins, increasing the throughput of later studies. The results presented here show the increased feasibility of wheat leaf proteomics and perhaps, plant proteomics in general.

\section{Identification of Protein Composition in Wheat Leaf}

Spots selected from 2-D gels were then digested with trypsin and the resultant peptides analyzed by MALDI-TOF. These proteins were identified by searching wheat and Viridiplantae protein sequences from Swiss-Prot and NCBI databases. In total, 200 spots (wheat proteins) were selected to be identified, based on reproducibility and relative quantity. Each spot containing approximately $0.2 \mu \mathrm{g}$ protein, and 123 proteins were putatively identified with an identification success rate of $61.5 \%$. The peptide mass fingerprint results were obtained by MALDI-Q-TOF, and the product ion spectra were generated by Q-TOF MS/MS. These identified proteins were assigned with a number and cataloged according to their $\mathrm{p} I$ and molecular weight (Table 2). Furthermore, among these 123 wheat proteins successfully identified from 2 -DE, there were only 47 unique ones. An identification success rate of $55 \%$ in barrel medic, utilizing both EST and protein databases which is comparable with the $51 \%$ identification success rate was observed with the dual protein/EST search method (Watson et al., 2003). Porubleva et al. (2001) reported that there was an identification success rate of $72 \%$ in maize leaves, but of the 216 proteins identified, less than 50 proteins were unique. Plant protein databases have grown substantially in the last few years, yielding higher rates of successful identifications from mass spectrometric data (Salt et al., 2005).

As shown in Fig. (2), there were 10, 21, 22, 47 and 23 wheat proteins identified from L2-L6, respectively. We found that the same wheat protein precipitated at different saturation levels of AS. According to the results, dehydroascorbate reductase, ascorbate peroxidase and putative 3-beta hydroxysteroid dehydrogenase were found in L5 and L6. Moreover, beta-amylase, phosphoglycerate mutase, ribulose bisphosphate carboxylase small chain clone 512 and ferredoxin$\operatorname{NADP}(\mathrm{H})$ oxidoreductase were found in L3-L4, L3-L5, L3L6 and L4-L5, respectively. We also found that there were multiple observations of the same wheat protein on a 2-D gel. Donnelly et al. (2005) reported that these multiple spots could be isoforms with different signal or targeted sequences, which would cause shifts in $\mathrm{p} I$ and molecular weight. The proteins could be post-translationally modified where the addition of side chains, phosphate, methyl groups, etc. affected the $\mathrm{p} I$ and molecular weight. Protein degradation could also be responsible for multiple spots of the same protein, or as is the case with Rubisco, the protein could be carbamylated or merely overabundant and streaking. Many of these same phenomena are also responsible for the discrepancies observed between the experimentally determined and database observed $\mathrm{p} I$ and molecular weights.

\section{Annotation of Wheat Leaf Proteins}

The annotations of these identified wheat proteins are shown in Table 3. This table shows lists of proteins for biological interpretation in the context of Gene Ontology, which organizes information according to their molecular function, biological processes and cellular components. Among 47 identified proteins, 42 proteins had ascertainable functional annotations. However, the remaining 5 proteins (hypothetical protein OSJNBb0081B07.22, OSJNBb0048E02.12 protein, hypothetical protein OJ1007_D04.29, hypothetical protein and putative hypersensitive-induced reaction protein) did not have any function annotation. Rostoks et al. (2003) reported that plant hypersensitive reaction is a defense response to pathogen infection involving rapid, localized cell death and the induction of many pathogenesis-related proteins such as hypersensitive-induced reaction protein. Yahata et al. (2005) also found several hypothetical proteins and proteins with unknown function from wheat.

Clark et al. (2005) reported that the GO project (http:// www.geneontology.org/) produces structured, controlled vocabularies and gene product annotations. Gene products were classified according to the cellular locations and biological process in which they act, and the molecular functions that they carry out. According to the results of GO annotation and classifications of proteins (Table 3 ), wheat proteins expressed different functions such as oxidoreductase, transferase and kinase activity in wheat leaf. Several wheat proteins including fructose-bisphosphate aldolase, phosphoglycerate mutase, malate dehydrogenase, putative malate dehydrogenase, cytosolic 3-phosphoglycerate kinase, phosphoglycerate kinase were involved in glycolysis. Plaxton et al. (1996) reported that glycolysis is important in plants because it is the predominant pathway that "fuels" plant respiration. Moreover, a significant proportion of the carbon that enters the plant glycolytic and TCA cycle pathways is not oxidized to $\mathrm{CO}_{2}$ but is utilized in the biosynthesis of numerous compounds such as secondary metabolites, isoprenoids, amino acids, nucleic acids, and fatty acids. These annotations provided the information to investigate the protein functions in wheat leaf.

\section{Functional Classifications of Wheat Leaf Proteins}

BGSSJ is an XML-based Java application that organizes information according to biological processes, molecular function and cellular components (Juan et al., 2006). The functional classifications of wheat proteins analyzed by BGSSJ were shown in Fig. (3). Of the 47 identified proteins, 42, 15 and 35 proteins already have information on their molecular function, cellular component and biological process, respectively. These proteins were classified and showed different functions in wheat leaf. Only five proteins lacked ascertainable functional annotation and others with an annotation success rate of $89.4 \%$. For molecular function, there were 37, 9 and 6 proteins with catalytic activity, binding and antioxidant activity, respectively. The classification of wheat proteins according to involved biological process, was 35 and 29 proteins with physiological process and cellular process respectively. Furthermore, for the classification of wheat proteins according to their involved cellular component, there were 12, 15 and 4 proteins with organelle component, cell and protein complex. Ashburner et al. (2000) reported that biological process refers to a biological objective to which the gene or gene product contributes. A process is accomplished via one or more ordered assemblies of molecular functions, while processes often involve a chemical or 
Table 2. Wheat Proteins Identified and Catalogued from the 2-DE

\begin{tabular}{|c|c|c|c|c|c|c|c|c|c|c|}
\hline 2 & $\mathrm{Cu} / \mathrm{Zn}$ superoxide dismutase & Q96123_WHEAT & 20000 & 5.4 & 20310 & 5.35 & 28 & 11 & MS/MS & Triticum aestivum \\
\hline 3 & Phosphoribulokinase & KPPR_WHEAT & 24000 & 4.9 & 45113 & 5.72 & 67 & 5 & MS/MS & Triticum aestivum \\
\hline 5 & Phosphoribulokinase & KPPR_WHEAT & 27000 & 5.2 & 45113 & 5.72 & 42 & 2 & MS/MS & Triticum aestivum \\
\hline 6 & $\begin{array}{l}\text { Putative hypersensitive- induced } \\
\text { reaction protein }\end{array}$ & Q6L4B0_SOLDE & 33000 & 5.7 & 32729 & 5.40 & 41 & 25 & MS & Solanum demissum \\
\hline 7 & Fructose-bisphosphate aldolase & ALFC_ORYSA & 41000 & 5.6 & 41980 & 6.38 & 33 & 2 & MS/MS & Oryza sativa \\
\hline 10 & Reversibly glycosylated polypeptide & Q9ZR33_WHEAT & 45000 & 5.8 & 41472 & 5.82 & 50 & 8 & MS/MS & Triticum aestivum \\
\hline 11 & $\begin{array}{l}\text { Ribulose bisphosphate carboxylase } \\
\text { small chain clone } 512\end{array}$ & RBS3_WHEAT & 15000 & 5.4 & 13046 & 5.84 & 25 & 36 & MS & Triticum aestivum \\
\hline 12 & Nucleoside diphosphate kinase & Q9LKM0_LOLPR & 18000 & 6.6 & 16491 & 6.30 & 75 & 11 & MS/MS & Lolium perenne \\
\hline 13 & Cyclophilin-like protein & Q6XPZ4_WHEAT & 24000 & 7.0 & 25875 & 9.59 & 68 & 7 & MS/MS & Triticum aestivum \\
\hline 14 & 2-cys peroxiredoxin BAS1 & BAS1_WHEAT & 24000 & 4.4 & 23312 & 5.71 & 62 & 15 & MS/MS & Triticum aestivum \\
\hline 15 & 2-cys peroxiredoxin BAS1 & BAS1_WHEAT & 24000 & 4.5 & 23312 & 5.71 & 137 & 22 & MS/MS & Triticum aestivum \\
\hline 16 & 2-cys peroxiredoxin BAS1 & BAS1_WHEAT & 24000 & 4.6 & 23312 & 5.71 & 235 & 26 & MS/MS & Triticum aestivum \\
\hline 22 & $\begin{array}{l}\text { ADP-glucose pyrophosphorylase } \\
\text { small subunit }\end{array}$ & Q7X9S8_HORVU & 30000 & 5.5 & 20497 & 6.23 & 59 & 5 & MS/MS & Hordeum vulgare \\
\hline 23 & Fructose-1,6-bisphosphatase & F16P1_PEA & 45000 & 5.2 & 44483 & 5.06 & 59 & 29 & MS & Pisum sativum \\
\hline 24 & Heat shock protein 70 & Q9SEW1_WHEAT & 52000 & 4.8 & 39680 & 4.56 & 74 & 3 & MS/MS & Triticum aestivum \\
\hline 25 & Heat shock protein 70 & Q9SEW1_WHEAT & 52000 & 4.9 & 39680 & 4.56 & 72 & 3 & MS/MS & Triticum aestivum \\
\hline 26 & Phosphoglycerate mutase & Q7XYD2_WHEAT & 81000 & 5.3 & 29558 & 5.43 & 138 & 14 & MS/MS & Triticum aestivum \\
\hline 27 & Phosphoglycerate mutase & Q7XYD2_WHEAT & 81000 & 5.5 & 29558 & 5.43 & 262 & 29 & MS/MS & Triticum aestivum \\
\hline 28 & Phosphoglycerate mutase & Q7XYD2_WHEAT & 81000 & 5.6 & 29558 & 5.43 & 173 & 23 & MS/MS & Triticum aestivum \\
\hline 29 & Phosphoglycerate mutase & Q7XYD2_WHEAT & 81000 & 5.7 & 29558 & 5.43 & 152 & 14 & MS/MS & Triticum aestivum \\
\hline 30 & Beta-amylase & AMYB_WHEAT & 67000 & 5.4 & 56575 & 5.24 & 80 & 7 & MS/MS & Triticum aestivum \\
\hline 31 & Isoprene synthase & Q6EJ97_PUELO & 67000 & 5.5 & 70030 & 5.60 & 44 & 23 & MS & Pueraria lobata \\
\hline 32 & $\begin{array}{l}\text { Ribulose bisphosphate carboxylase } \\
\text { small chain clone } 512\end{array}$ & RBS3_WHEAT & 15000 & 5.2 & 13046 & 5.84 & 25 & 36 & MS & Triticum aestivum \\
\hline 33 & $\begin{array}{l}\text { Ribulose bisphosphate carboxylase } \\
\text { small chain clone } 512\end{array}$ & RBS3_WHEAT & 15000 & 5.3 & 13046 & 5.84 & 25 & 36 & MS & Triticum aestivum \\
\hline
\end{tabular}


(Table 2) contd....

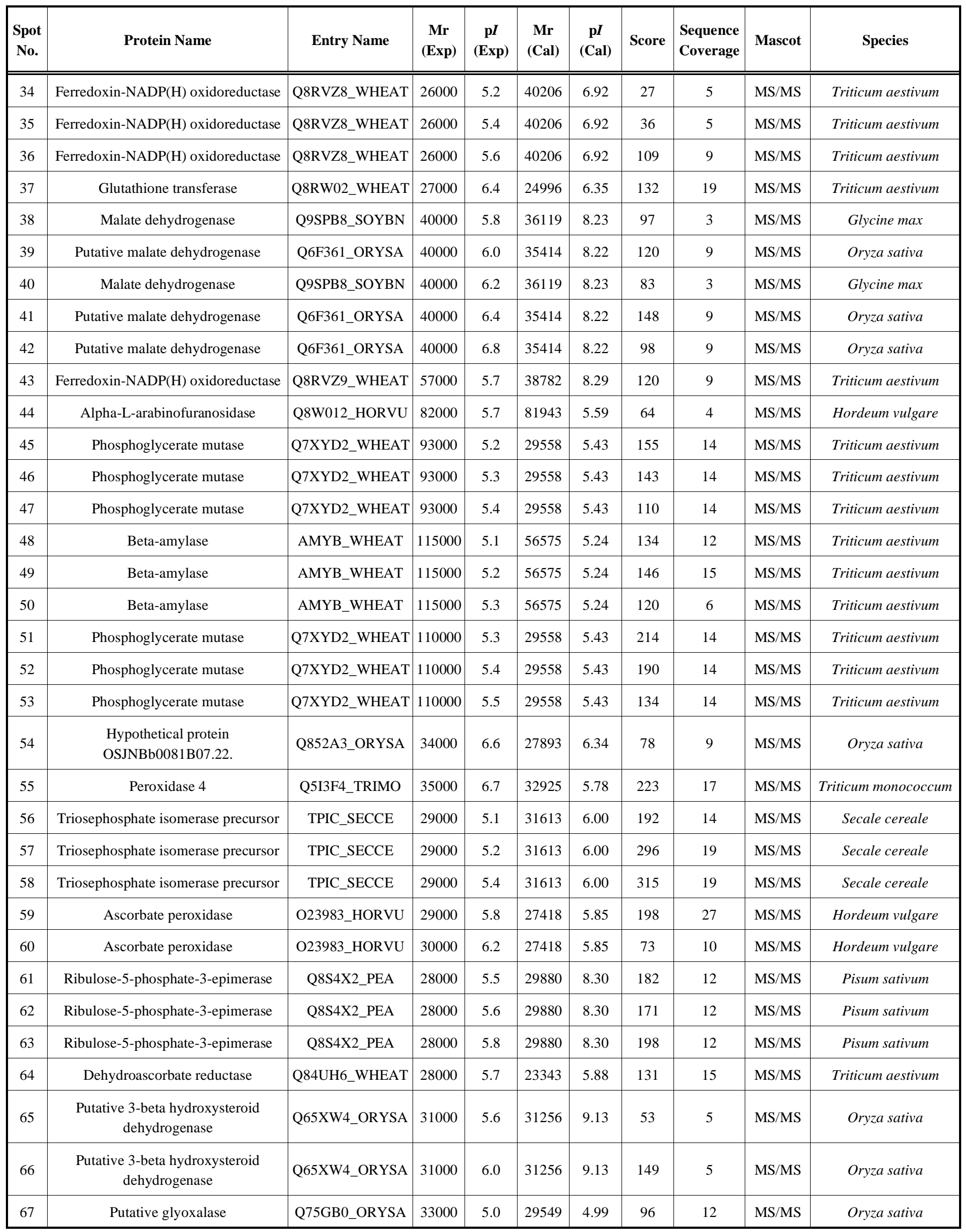


(Table 2) contd....

\begin{tabular}{|c|c|c|c|c|c|c|c|c|c|c|}
\hline $\begin{array}{l}\text { Spot } \\
\text { No. }\end{array}$ & Protein Name & Entry Name & $\begin{array}{c}\mathrm{Mr} \\
(\operatorname{Exp})\end{array}$ & $\begin{array}{c}\mathbf{p} I \\
(\operatorname{Exp})\end{array}$ & $\begin{array}{c}\mathrm{Mr} \\
(\mathrm{Cal})\end{array}$ & $\begin{array}{c}\mathbf{p I} \\
(\mathrm{Cal})\end{array}$ & Score & $\begin{array}{l}\text { Sequence } \\
\text { Coverage }\end{array}$ & Mascot & Species \\
\hline 68 & Ferredoxin-NADP $(H)$ oxidoreductase & Q8RVZ8_WHEAT & 33000 & 5.1 & 40206 & 6.92 & 267 & 16 & MS/MS & Triticum aestivum \\
\hline 69 & Ferredoxin-NADP $(\mathrm{H})$ oxidoreductase & Q8RVZ8_WHEAT & 33000 & 5.2 & 40206 & 6.92 & 178 & 9 & MS/MS & Triticum aestivum \\
\hline 70 & Ferredoxin-NADP $(H)$ oxidoreductase & Q8RVZ8_WHEAT & 35000 & 5.3 & 40206 & 6.92 & 160 & 9 & $\mathrm{MS} / \mathrm{MS}$ & Triticum aestivum \\
\hline 71 & Ferredoxin-NADP $(\mathrm{H})$ oxidoreductase & Q8RVZ9_WHEAT & 34000 & 5.6 & 38782 & 8.29 & 226 & 16 & $\mathrm{MS} / \mathrm{MS}$ & Triticum aestivum \\
\hline 72 & Ferredoxin-NADP $(H)$ oxidoreductase & Q8RVZ8_WHEAT & 34000 & 5.8 & 40206 & 6.92 & 73 & 5 & MS/MS & Triticum aestivum \\
\hline 73 & Ferredoxin-NADP $(\mathrm{H})$ oxidoreductase & Q8RVZ9_WHEAT & 37000 & 6.9 & 38782 & 8.29 & 221 & 12 & MS/MS & Triticum aestivum \\
\hline 74 & $\begin{array}{l}\text { Hypothetical protein } \\
\text { OSJNBb0081B07.22. }\end{array}$ & Q852A3_ORYSA & 33000 & 6.0 & 27893 & 6.34 & 76 & 9 & MS/MS & Oryza sativa \\
\hline 75 & Peroxidase 5 & Q5I3F3_TRIMO & 34000 & 6.0 & 27533 & 5.75 & 61 & 5 & $\mathrm{MS} / \mathrm{MS}$ & Triticum monococcum \\
\hline 76 & OSJNBa0042F21.13 protein & Q7XRT0_ORYSA & 45000 & 4.7 & 42218 & 5.64 & 148 & 18 & $\mathrm{MS} / \mathrm{MS}$ & Oryza sativa \\
\hline 77 & OSJNBa0042F21.13 protein & Q7XRT0_ORYSA & 45000 & 4.8 & 42218 & 5.64 & 258 & 14 & $\mathrm{MS} / \mathrm{MS}$ & Oryza sativa \\
\hline 78 & Cytosolic 3-phosphoglycerate kinase & Q850M3_WHEAT & 46000 & 5.4 & 31315 & 4.98 & 220 & 19 & MS/MS & Triticum aestivum \\
\hline 79 & Cytosolic 3-phosphoglycerate kinase & Q850M3_WHEAT & 46000 & 5.6 & 31315 & 4.98 & 247 & 19 & $\mathrm{MS} / \mathrm{MS}$ & Triticum aestivum \\
\hline 80 & Cytosolic 3-phosphoglycerate kinase & Q850M3_WHEAT & 46000 & 5.8 & 31315 & 4.98 & 227 & 16 & $\mathrm{MS} / \mathrm{MS}$ & Triticum aestivum \\
\hline 81 & Cytosolic 3-phosphoglycerate kinase & Q850M3_WHEAT & 46000 & 5.9 & 31315 & 4.98 & 113 & 13 & MS/MS & Triticum aestivum \\
\hline 82 & HSP70. & Q9SAU8_WHEAT & 48000 & 6.0 & 70986 & 5.14 & 140 & 8 & $\mathrm{MS} / \mathrm{MS}$ & Triticum aestivum \\
\hline 83 & HSP70. & Q9SAU8_WHEAT & 48000 & 6.3 & 70986 & 5.14 & 120 & 6 & MS/MS & Triticum aestivum \\
\hline 84 & HSP70. & Q9SAU8_WHEAT & 48000 & 6.6 & 70986 & 5.14 & 51 & 2 & MS/MS & Triticum aestivum \\
\hline 85 & $\begin{array}{l}\text { UTP-glucose-1-phosphate } \\
\text { uridylyltransferase }\end{array}$ & UGPA_HORVU & 63000 & 4.8 & 51612 & 5.20 & 243 & 14 & MS/MS & barley \\
\hline 86 & $\begin{array}{l}\text { UTP-glucose-1-phosphate } \\
\text { uridylyltransferase }\end{array}$ & UGPA_HORVU & 63000 & 4.9 & 51612 & 5.20 & 261 & 14 & MS/MS & barley \\
\hline 87 & $\begin{array}{l}\text { UTP-glucose-1-phosphate } \\
\text { uridylyltransferase }\end{array}$ & UGPA_HORVU & 63000 & 5.0 & 51612 & 5.20 & 252 & 14 & MS/MS & barley \\
\hline 88 & $\begin{array}{l}\text { UTP-glucose-1-phosphate } \\
\text { uridylyltransferase }\end{array}$ & UGPA_HORVU & 63000 & 5.1 & 51612 & 5.20 & 225 & 14 & MS/MS & barley \\
\hline 89 & Phosphoglycerate kinase & PGKY_WHEAT & 56000 & 5.5 & 42096 & 5.64 & 207 & 15 & MS/MS & Triticum aestivum \\
\hline 90 & Phosphoglycerate kinase & PGKY_WHEAT & 56000 & 5.7 & 42096 & 5.64 & 138 & 15 & $\mathrm{MS} / \mathrm{MS}$ & Triticum aestivum \\
\hline 91 & Phosphoglycerate kinase & PGKY_WHEAT & 58000 & 5.7 & 42096 & 5.64 & 54 & 4 & MS/MS & Triticum aestivum \\
\hline 92 & Phosphoglycerate mutase & Q7XYD2_WHEAT & 80000 & 5.3 & 29558 & 5.43 & 75 & 11 & MS/MS & Triticum aestivum \\
\hline 93 & Phosphoglycerate mutase & Q7XYD2_WHEAT & 80000 & 5.4 & 29558 & 5.43 & 112 & 11 & MS/MS & Triticum aestivum \\
\hline 94 & OSJNBb0003B01.27 protein & Q5JQX8_ORYSA & 85000 & 5.5 & 89177 & 6.49 & 20 & 2 & MS/MS & Oryza sativa \\
\hline 95 & OSJNBb0003B01.27 protein & Q5JQX8_ORYSA & 85000 & 5.7 & 89177 & 6.49 & 13 & 2 & $\mathrm{MS} / \mathrm{MS}$ & Oryza sativa \\
\hline 96 & Cytosolic 3-phosphoglycerate kinase & Q850M3_WHEAT & 90000 & 5.4 & 31315 & 4.98 & 148 & 17 & $\mathrm{MS} / \mathrm{MS}$ & Triticum aestivum \\
\hline 97 & S222. & Q9ZTU6_WHEAT & 100000 & 5.3 & 50111 & 5.86 & 46 & 3 & MS/MS & Triticum aestivum \\
\hline 98 & S222. & Q9ZTU6_WHEAT & 100000 & 5.5 & 50111 & 5.86 & 69 & 3 & $\mathrm{MS} / \mathrm{MS}$ & Triticum aestivum \\
\hline 99 & S222. & Q9ZTU6_WHEAT & 100000 & 5.7 & 50111 & 5.86 & 60 & 7 & MS/MS & Triticum aestivum \\
\hline 100 & S222. & Q9ZTU6_WHEAT & 100000 & 5.9 & 50111 & 5.86 & 31 & 3 & MS/MS & Triticum aestivum \\
\hline
\end{tabular}


(Table 2) contd....

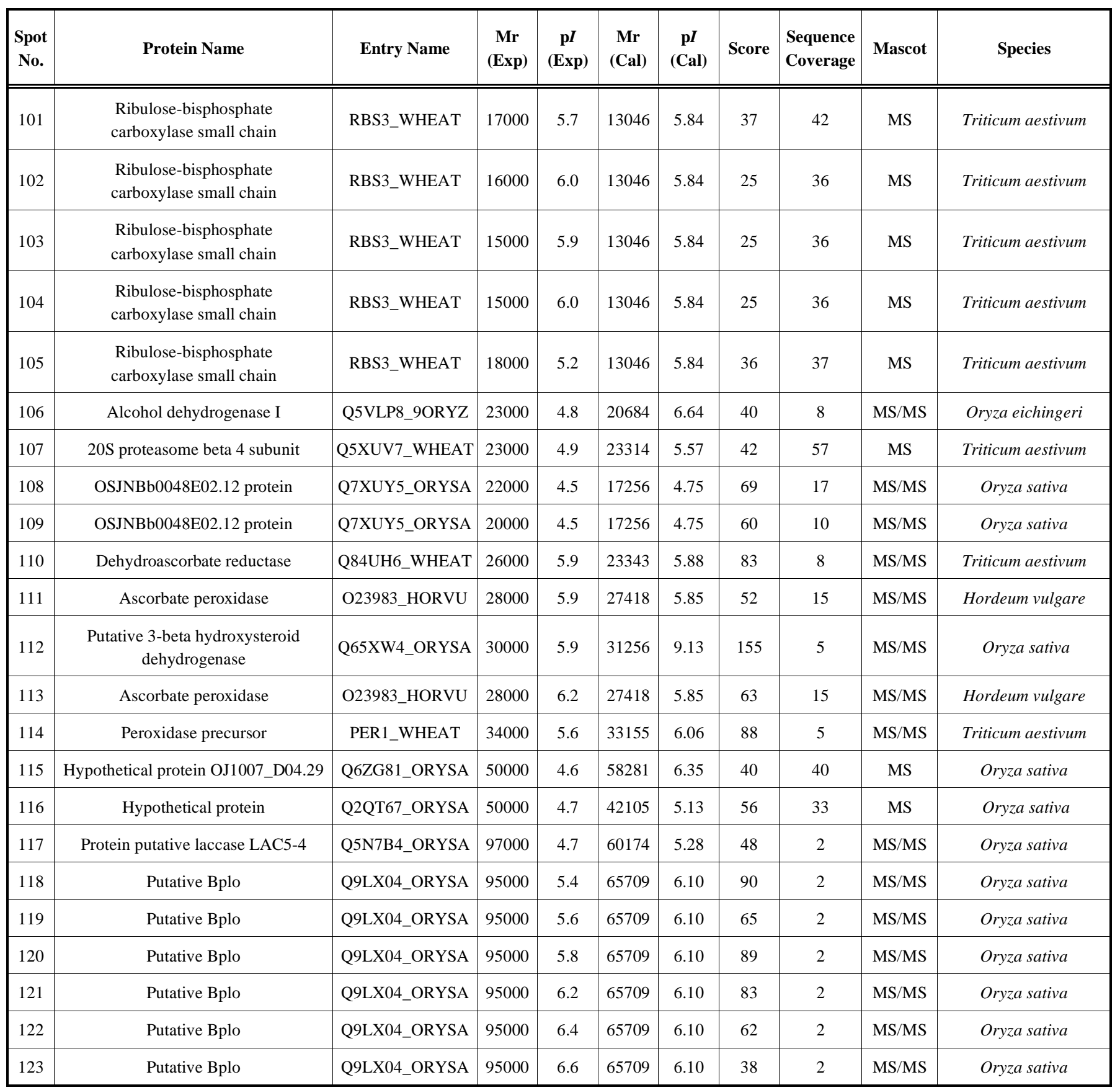

physical transformation. Nevertheless, cellular component refers to the place in the cell where a gene product is active. The information obtained from our results should be useful for any future study on the wheat leaf.

\section{Molecular Function of Identified Proteins in Wheat Leaf}

Wheat proteins grouped under molecular function were involved in catalytic activity, binding activity and antioxidant activity (Fig. 3). The catalytic activity of wheat proteins included oxidoreductase, transferase, hydrolase, lyase and isomerase activity. Furthermore, phosphoribulokinase, nucleoside diphosphate kinase and heat shock protein 70 had nucleotide binding activity. We also found ascorbate peroxidase, peroxidase, $\mathrm{Cu} / \mathrm{Zn}$ superoxide dismutase and 2-cys peroxiredoxin BAS1 with antioxidant activity. As we know, active oxygen species such as superoxide and hydroxyl radicals are by-products of normal cell metabolism. These active oxygen species result in the peroxidation of membrane lipids, breakage of DNA strands and inactivation of enzymes (Muth et al., 2004). The conditions leading to damage caused by active oxygen species are referred to as oxidative stress. Wu et al. (1999) reported that these enzymes with antioxidant activity in wheat could protect cells from superoxide radicals by catalyzing the dismutation of the superoxide radical to molecular $\mathrm{O}_{2}$ and $\mathrm{H}_{2} \mathrm{O}_{2}$. 
Table 3. Annotation of Identified Wheat Proteins from the 2-DE

\begin{tabular}{|c|c|c|}
\hline Protein Name & Spot No. & Annotation (Gene Ontology, GO) \\
\hline Ascorbate peroxidase & $\begin{array}{l}59,60,111 \\
113\end{array}$ & $\begin{array}{l}\text { GO: 0016688; Molecular function: L-ascorbate peroxidase activity. } \\
\text { GO: 0016491; Molecular function: oxidoreductase activity. } \\
\text { GO: 0006979; Biological process: response to oxidative stress. }\end{array}$ \\
\hline $\begin{array}{l}\text { Ribulose bisphosphate } \\
\text { carboxylase small chain clone } 512\end{array}$ & $\begin{array}{c}11,32,33 \\
101-105\end{array}$ & Function: It catalyzes two reactions: the carboxylation of D-ribulose 1,5-bisphosphate. \\
\hline Phosphoglycerate kinase & $89-91$ & $\begin{array}{l}\text { Catalytic activity: ATP + 3-phospho-D-glycerate = ADP + 3-phospho-D-glyceroyl phosphate. } \\
\text { Pathway: glycolysis. }\end{array}$ \\
\hline Phosphoribulokinase & $3-5$ & $\begin{array}{l}\text { Enzyme regulation: Light regulated via thioredoxin by reversible oxidation/reduction of sulfhydryl/ } \\
\text { disulfide groups. }\end{array}$ \\
\hline $\begin{array}{l}\text { Triosephosphate isomerase } \\
\text { precursor }\end{array}$ & $56-58$ & $\begin{array}{l}\text { Catalytic activity: D-glyceraldehyde 3-phosphate = glycerone phosphate. } \\
\text { Pathway: Calvin cycle. }\end{array}$ \\
\hline Fructose-1,6-bisphosphatase & 23 & $\begin{array}{l}\text { Pathway: The chloroplast isozyme takes part in the regeneration of ribulose bisphosphate in the } \\
\text { photosynthetic carbon reduction cycle. }\end{array}$ \\
\hline 2-cys peroxiredoxin BAS1 & $14-20$ & $\begin{array}{l}\text { Function: May be an antioxidant enzyme particularly in the developing shoot and photosynthesizing leaf. } \\
\text { PTM: The Cys-64-SH group is the primary site of oxidation by } \mathrm{H}_{2} \mathrm{O}_{2} \text {, and the oxidized Cys-64 rapidly } \\
\text { reacts with Cys-185-SH of the other subunit to form an intermolecular disulfide. }\end{array}$ \\
\hline Beta-amylase & $30,48-50$ & Catalytic activity: Hydrolysis of 1,4-alpha-D-glucosidic linkages in polysaccharides. \\
\hline Peroxidase precursor & 114 & $\begin{array}{l}\text { Function: Removal of } \mathrm{H}_{2} \mathrm{O}_{2} \text {, oxidation of toxic reductants, biosynthesis and degradation of lignin, } \\
\text { suberization, auxi. }\end{array}$ \\
\hline Fructose-bisphosphate aldolase & 7 & GO:0004332; Molecular function: fructose-bisphosphate aldolase activity. \\
\hline $\begin{array}{l}\text { UTP-glucose-1-phosphate } \\
\text { uridylyltransferase }\end{array}$ & $85-88$ & Function: Plays a central role as a glucosyl donor in cellular metabolic pathways. \\
\hline $\begin{array}{l}\text { Peroxidase } 4 \\
\text { Peroxidase } 5\end{array}$ & $\begin{array}{l}55 \\
75\end{array}$ & $\begin{array}{l}\text { GO:0005506; Molecular function: iron ion binding. } \\
\text { GO:0046872; Molecular function: metal ion binding. } \\
\text { GO:0016491; Molecular function: oxidoreductase activity. } \\
\text { GO:0004601; Molecular function: peroxidase activity. } \\
\text { GO:0006979; Biological process: response to oxidative stress. }\end{array}$ \\
\hline OSJNBb0003B01.27 protein & 94,95 & $\begin{array}{l}\text { GO:0004553; Molecular function: hydrolase activity. } \\
\text { GO:0005975; Biological process: carbohydrate metabolism. }\end{array}$ \\
\hline Protein putative laccase LAC5-4 & 117 & $\begin{array}{l}\text { GO:0005507; Molecular function: copper ion binding. } \\
\text { GO:0046872; Molecular function: metal ion binding. } \\
\text { GO:0016491; Molecular function: oxidoreductase activity. }\end{array}$ \\
\hline Alcohol dehydrogenase I & 106 & $\begin{array}{l}\text { GO:0046872; Molecular function: metal ion binding. } \\
\text { GO:0016491; Molecular function: oxidoreductase activity. } \\
\text { GO:0008270; Molecular function: zinc ion binding. }\end{array}$ \\
\hline $20 \mathrm{~S}$ proteasome beta 4 subunit & 107 & $\begin{array}{l}\text { GO:0005829; Cellular component: cytosol. } \\
\text { GO:0005839; Cellular component: proteasome core complex. } \\
\text { GO:0043234; Cellular component: protein complex. } \\
\text { GO:0004298; Molecular function: threonine endopeptidase activity. } \\
\text { GO:0006511; Biological process: ubiquitin-dependent protein catabolism. }\end{array}$ \\
\hline $\begin{array}{l}\text { Putative 3-beta hydroxysteroid } \\
\text { dehydrogenase }\end{array}$ & $65,66,112$ & $\begin{array}{l}\text { GO:0016853; Molecular function: isomerase activity. } \\
\text { GO:0051287; Molecular function: NAD binding. } \\
\text { GO:0009225; Biological process: nucleotide-sugar metabolism. }\end{array}$ \\
\hline Isoprene synthase & 31 & $\begin{array}{l}\text { GO:0016829; Molecular function: lyase activity. } \\
\text { GO:0008152; Biological process: metabolism. }\end{array}$ \\
\hline
\end{tabular}




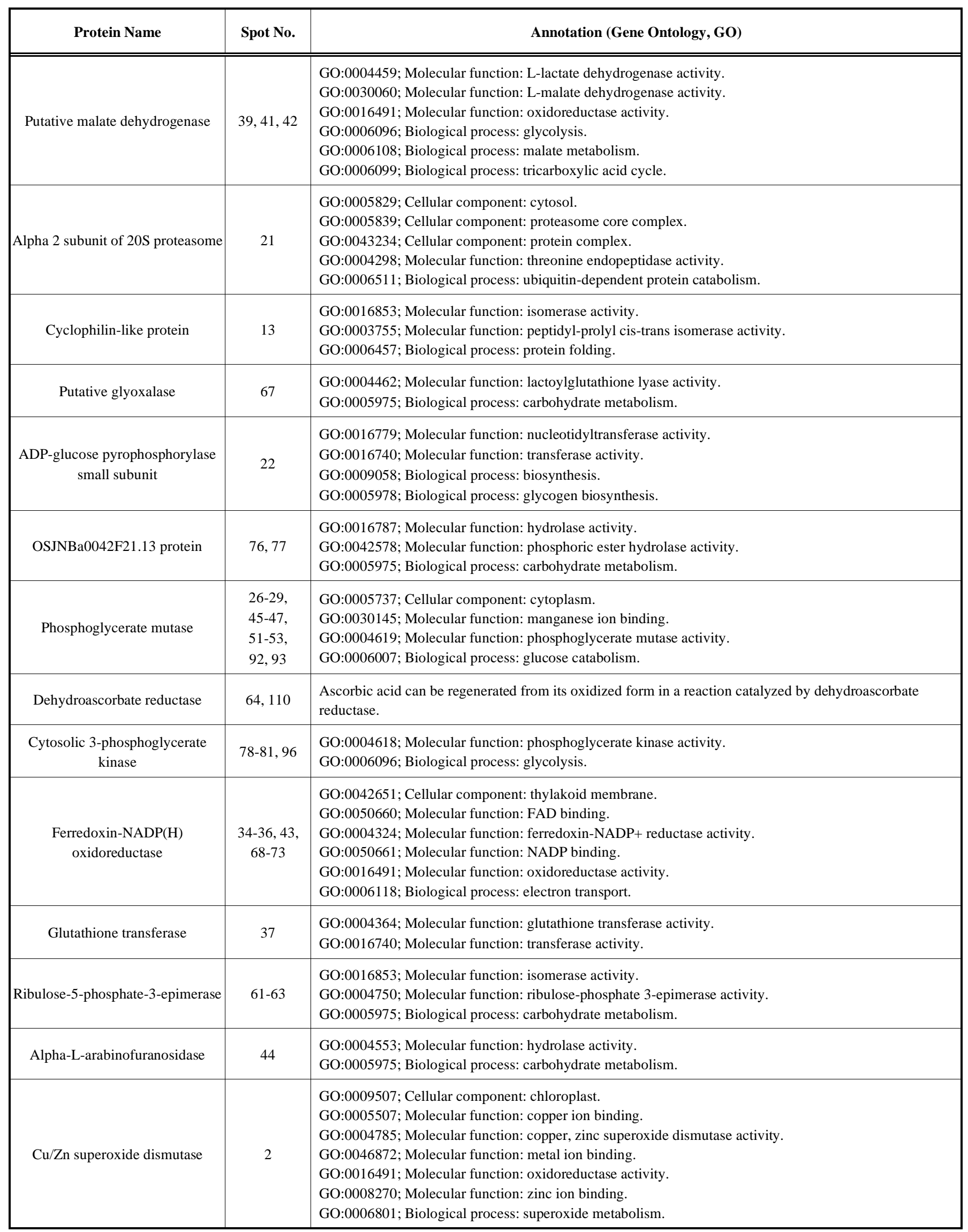


(Table 3) contd....

\begin{tabular}{|c|c|c|}
\hline $\begin{array}{l}\text { Ribulose-1,5-bisphosphate } \\
\text { carboxylase }\end{array}$ & 1 & $\begin{array}{l}\text { GO:0009573; Cellular component: ribulose bisphosphate carboxylase complex. } \\
\text { GO:0016984; Molecular function: ribulose-bisphosphate carboxylase activity. } \\
\text { GO:0015977; Biological process: carbon utilization by fixation of carbon dioxide. }\end{array}$ \\
\hline Nucleoside diphosphate kinase & 12 & $\begin{array}{l}\text { GO:0005524; Molecular function: ATP binding. } \\
\text { GO:0016301; Molecular function: kinase activity. } \\
\text { GO:0000287; Molecular function: magnesium ion binding. } \\
\text { GO:0004550; Molecular function: nucleoside diphosphate kinase activity. } \\
\text { GO:0000166; Molecular function: nucleotide binding. } \\
\text { GO:0016740; Molecular function: transferase activity. } \\
\text { GO:0006241; Biological process: CTP biosynthesis. } \\
\text { GO:0006183; Biological process: GTP biosynthesis. } \\
\text { GO:0006228; Biological process: UTP biosynthesis. }\end{array}$ \\
\hline Heat shock protein 70 & 24,25 & $\begin{array}{l}\text { GO:0005524; Molecular function: ATP binding. } \\
\text { GO:0006457; Biological process: protein folding. } \\
\text { GO:0006986; Biological process: response to unfolded protein. }\end{array}$ \\
\hline Malate dehydrogenase & 38,40 & $\begin{array}{l}\text { GO:0004459; Molecular function: L-lactate dehydrogenase activity. } \\
\text { GO:0030060; Molecular function: L-malate dehydrogenase activity. } \\
\text { GO:0016491; Molecular function: oxidoreductase activity. } \\
\text { GO:0006096; Biological process: glycolysis. } \\
\text { GO:0006108; Biological process: malate metabolism. } \\
\text { GO:0006099; Biological process: tricarboxylic acid cycle. }\end{array}$ \\
\hline
\end{tabular}

\section{Cellular Component and Biological Process of Identified Proteins in Wheat Leaf}

Of those identified wheat proteins, 15 identified proteins were involved in cellular component of which 13 proteins were intracellular proteins. All of these intracellular proteins were in cytoplasm, while 2 wheat proteins including alpha 2 subunit of $20 \mathrm{~S}$ proteasome and $20 \mathrm{~S}$ proteasome beta 4 subunit were also found in the nucleus. Moreover, reversibly glycosylated polypeptide and ferredoxin-NADP $(\mathrm{H})$ oxidoreductase were the components of cell wall and membrane, respectively. Dhugga et al. (1997) indicated that reversibly glycosylated polypeptide was possibly involved in plant cell wall synthesis. Matthijs et al. (1986) reported that the reduction of $\mathrm{NADP}^{+}$by ferredoxin:NADP ${ }^{+}$oxidoreductase is the terminal step in the electron transport chain of the thylakoid, and the point at which the reductant is delivered to the stromal compartment. In addition, total of 35 wheat proteins were grouped in biological process of which 5 proteins were clustered in photosynthesis. These were identified as ribulose-1,5-bisphosphate carboxylase, phosphoribulokinase, ribulose bisphosphate carboxylase small chain clone 512, fructose-1,6-bisphosphatase and triosephosphate isomerase. Whitney et al. (2003) suggested that all plants depend on the photosynthetic $\mathrm{CO}_{2}$-fixing enzyme (ribulose-1,5-biphosphote carboxylase, Rubisco) to supply them with combined carbon. Rubisco of tobacco with the dimeric version from the bacterium, Rhodospirillum rubrum, resulted in fully autotrophic and reproductive tobacco plants that required high $\mathrm{CO}_{2}$ concentrations to grow.

\section{CONCLUSION}

In this study, we used two-dimensional electrophoresis, mass spectrometry and bioinformatic software to investigate wheat leaf proteins' composition and function. Compared with previous publications (Bahrman et al., 2004; Donnelly, et al. 2005), our results show that the proteins could be salted out by ammonium sulfate and separated electrophoretically in the $2 \mathrm{D}$ gels. A total of 123 wheat proteins were 
A

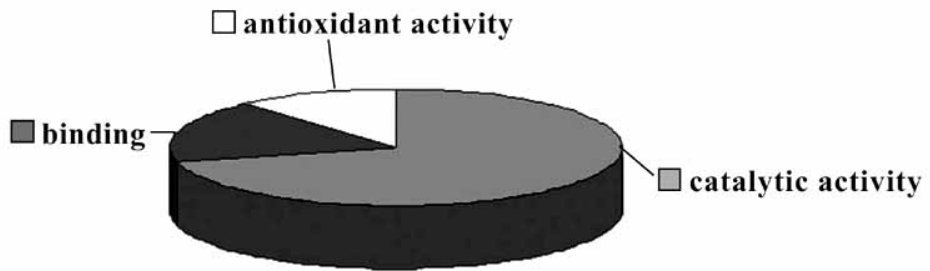

Molecular function

B

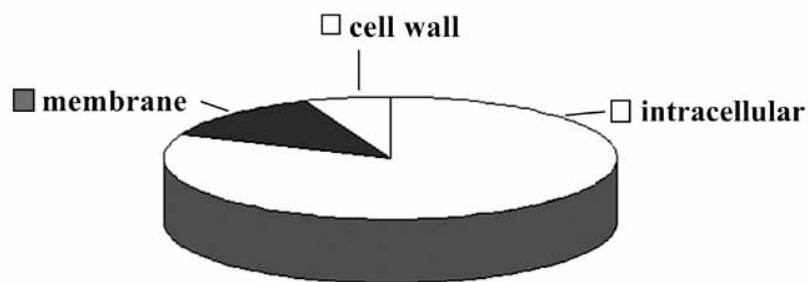

Cellular component

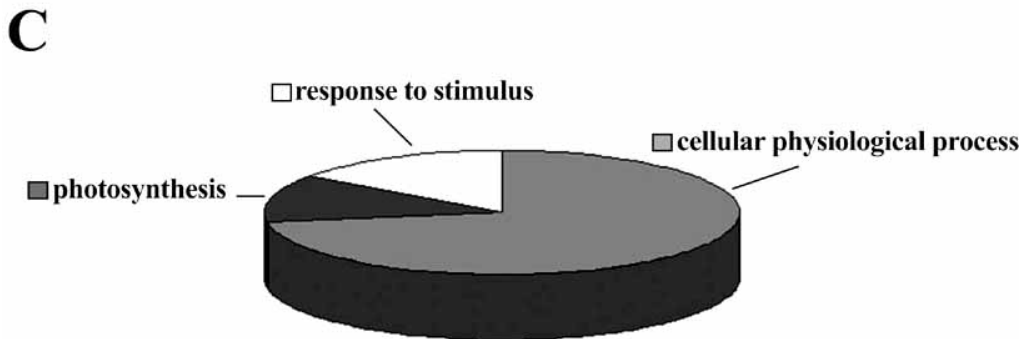

\section{Biological process}

Fig. (3). Functional classifications of identified wheat proteins from 2-DE. A: molecular function; B: cellular component; C: biological process.

putatively identified with an identification success rate of $61.5 \%$. These wheat protein maps generated will also enable future proteomic studies to focus on differential expression by using the identified proteins as reference proteins. In addition, the annotations and classifications of the identified proteins by bioinformatic software were also completed. It shows lists of proteins for biological interpretation in the context of Gene Ontology, which organizes information according to their molecular function, biological processes and cellular components. This information should be useful for any future study on the wheat leaf and perhaps, other plants in general.

\section{ABBREVIATIONS}

$\begin{array}{ll}\text { 2-DE } & =\text { Two-Dimensional gel electrophoresis } \\ \mathrm{ACN} & =\text { Acetonitrile } \\ \mathrm{AS} & =\text { Ammonium sulfate } \\ \beta-\mathrm{Me} & =\beta \text {-Mercaptoethanol } \\ \mathrm{BGSS} & =\text { Bulk Gene Search System } \\ \mathrm{IPG} & =\text { Immobilized pH gradient }\end{array}$

MS = Mass spectrometry

SDS-PAGE = Sodium dodecyl sulfate-polyacrylamide gel electrophoresis

TCA $=$ Trichloroacetic acid

TFA $=$ Trifluoroacetic acid

\section{REFERENCES}

Ahram, M., Best, C.J., Flaig, M.J., Gillespie, J.W., Leiva, I.M., Chuaqui, R.F., Zhou, G., Shu, H., et al. (2002). Proteomic analysis of human prostate cancer. Mol. Carcinog. 33: 9-15.

Ashburner, M., Ball, C.A., Blake, J.A., Botstein, D., Butler, H., Cherry, J.M., Davis, A.P., Dolinski, K., et al. (2000). Gene ontology: Tool for the unification of biology. The gene ontology consortium. Nat. Genet. 25: 25-9.

Bahrman, N., Negroni, L., Jaminon, O. and Le, G.J. (2004). Wheat leaf proteome analysis using sequence data of proteins separated by twodimensional electrophoresis. Proteomics 4: 2672-84.

Berggren, K., Chernokalskaya, E., Steinberg, T.H., Kemper, C., Lopez, M.F., Diwu, Z., Haugland, R.P. and Patton, W.F. (2000). Backgroundfree, high sensitivity staining of proteins in one- and two-dimensional sodium dodecyl sulfate-polyacrylamide gels using a luminescent ruthenium complex. Electrophoresis 21: 2509-21.

Chao, Y.C. and Nylander-French, L.A. (2004). Determination of keratin protein in a tape-stripped skin sample from jet fuel exposed skin. Ann. Occup. Hyg. 48: 65-73. 
Clark, J.I., Brooksbank, C. and Lomax, J. (2005). It's all GO for plant scientists. Plant Physiol. 138: 1268-79.

Dhingra, V., Li, Q., Allison, A.B., Stallknecht, D.E. and Fu, Z.F. (2005). Proteomic profiling and neurodegeneration in west-nile-virus-infected neurons. J. Biomed. Biotechnol. 2005: 271-9.

Dhugga, K.S., Tiwari, S.C. and Ray, P.M. (1997). A reversibly glycosylated polypeptide possibly involved in plant cell wall synthesis: purification, gene cloning, and trans-Golgi localization. Proc. Natl. Acad. Sci. USA 94: 7679-84.

Donnelly, B.E., Madden, R.D., Ayoubi, P., Porter, D.R. and Dillwith, J.W. (2005). The wheat (Triticum aestivum L.) leaf proteome. Proteomics $\mathbf{5}$ : 1624-33.

Englard, S. and Seifter, S. (1990). Precipitation techniques. Methods Enzymol. 182: 285-300.

Farag, A.M. and Hassan, M.A. (2004). Purification, characterization and immobilization of a keratinase from Aspergillus oryzae. Enzyme Microb. Technol. 34: 85-93.

Gygi, S.P. and Aebersold, R. (2000). Mass spectrometry and proteomics. Curr. Opin. Chem. Biol. 4: 489-94.

Juan, H.F., Lin, J.Y., Chang, W.H., Wu, C.Y., Pan, T.L., Tseng, M.J., Khoo, K.H. and Chen, S.T. (2002). Biomic study of human myeloid leukemia cells differentiation to macrophages using DNA array, proteomic, and bioinformatic analytical methods. Electrophoresis 23: 2490-504.

Juan, H.F., Wang, I.H., Huang, T.C., Li, J.J., Chen, S.T. and Huang, H.C. (2006). Proteomics analysis of a novel compound: cyclic RGD in breast carcinoma cell line MCF-7. Proteomics 6: 2991-3000.

Kochkina, V.M. (2004). Isolation, purification and crystallization of aspartate aminotransferase from wheat grain. Biochem. (Mosc.) 69: 897-900.

Matthijs, H.C., Coughlan, S.J. and Hind, G. (1986). Removal of ferredoxin: $\mathrm{NADP}^{+}$oxidoreductase from thylakoid membranes, rebinding to depleted membranes, and identification of the binding site. J. Biol. Chem. 261: $12154-8$

Morrissey, B. and Downard, K.M. (2006). A proteomics approach to survey the antigenicity of the influenza virus by mass spectrometry. Proteomics 6: 2034-41.

Muth, C.M., Glenz, Y., Klaus, M., Radermacher, P., Speit, G. and Leverve, $X$. (2004). Influence of an orally effective SOD on hyperbaric oxygenrelated cell damage. Free Radic. Res. 38: 927-32.

Patterson, S.D. and Aebersold, R. (1995). Mass spectrometric approaches for the identification of gel-separated proteins. Electrophoresis 16: 1791-814.

Plaxton, W.C. (1996). The organization and regulation of plant glycolysis. Annu. Rev. Plant Physiol. Plant Mol. Biol. 47: 185-214.

Porubleva, L., Vander, V.K., Kothari, S., Oliver, D.J. and Chitnis, P.R. (2001). The proteome of maize leaves: use of gene sequences and expressed sequence tag data for identification of proteins with peptide mass fingerprints. Electrophoresis 22: 1724-38.

Rampitsch, C., Bykova, N.V., McCallum, B., Beimcik, E. and Ens, W. (2006). Analysis of the wheat and Puccinia triticina (leaf rust) proteo- mes during a susceptible host-pathogen interaction. Proteomics 6: $1897-907$.

Rashidi, H.H. and Buehler, L.K. (2000). Bioinformatics basics: Application in biological science and medicine, CRC Press, Boca Raton, pp. 133-4.

Rostoks, N., Schmierer, D., Kudrna, D. and Kleinhofs, A. (2003). Barley putative hypersensitive induced reaction genes: genetic mapping, sequence analyses and differential expression in disease lesion mimic mutants. Theor. Appl. Genet. 107: 1094-101.

Salt, L.J., Robertson, J.A., Jenkins, J.A., Mulholland, F. and Mills, E.N. (2005). The identification of foam-forming soluble proteins from wheat (Triticum aestivum) dough. Proteomics 5: 1612-23.

Saxena, S.K., Ibrahim, A.N., Chaudhury, S. and Thukral, S.S. (2000). Development of a computer software for analysis of SDS-PAGE protein fingerprints of bacterial isolates. Indian J. Exp. Biol. 38: 167-76.

$\mathrm{Su}$, T.M. and Yang, Y.S. (2000). Identification, purification and characterization of a thermophilic imidase from pig liver. Protein Expr. Purif. 19 $289-97$.

Tantipaiboonwong, P., Sinchaikul, S., Sriyam, S., Phutrakul, S. and Chen, S.T. (2005). Different techniques for urinary protein analysis of normal and lung cancer patients. Proteomics 5: 1140-9.

Topanurak, S., Sinchaikul, S., Phutrakul, S., Sookkheo, B. and Chen, S.T. (2005). Proteomics viewed on stress response of thermophilic bacterium Bacillus stearothermophilus TLS33. Proteomics 5: 3722-30.

Trisiriroj, A., Jeyachok, N. and Chen, S.T. (2004). Proteomics characterization of different bran proteins between aromatic and nonaromatic rice (Oryza sativa L. ssp. indica). Proteomics 4: 2047-57.

Wan, J., Wang, J. and Cheng, H. (2001). Proteomic analysis of apoptosis initiation induced by all-trans retinoic acid in human acute promyelocytic leukemia cells. Electrophoresis 22: 3026-37.

Watson, B.S., Asirvatham, V.S., Wang, L. and Sumner, L.W. (2003). Mapping the proteome of barrel medic (Medicago truncatula). Plant Physiol. 131: 1104-23.

Whitney, S.M. and Andrews, T.J. (2003). Photosynthesis and growth of tobacco with a substituted bacterial Rubisco mirror the properties of the introduced enzyme. Plant Physiol. 133: 287-94.

Wu, G., Wilen, R.W., Robertson, A.J. and Gusta, L.V. (1999). Isolation, chromosomal localization and differential expression of mitochondrial manganese superoxide dismutase and chloroplastic copper/zinc superoxide dismutase genes in wheat. Plant Physiol. 120: 513-20.

Wu, T.L. (2006). Two-dimensional difference gel electrophoresis. Methods Mol. Biol. 328: 71-95.

Yahata, E., Maruyama-Funatsuki, W., Nishio, Z., Tabiki, T., Takata, K., Yamamoto, Y., Tanida, M. and Saruyama, H. (2005). Wheat cultivarspecific proteins in grain revealed by 2-DE and their application to cultivar identification of flour. Proteomics 5: 3942-53.

Yates, J.R. (2000). Mass spectrometry: from genomics to proteomics. Trends Genet. 16: 5-8.

Received: October 18, $2007 \quad$ Revised: October 10, $2008 \quad$ Accepted: October 13, 2008 